\title{
QUALITY OF WORK LIFE OF EDUCATORS IN LEBANESE FRENCH UNIVERSITY
}

\author{
Dr Kiran Das Naik Eslavath \\ Assistant Professor, Research and Strategic Studies \\ Lebanese French University, Iraq \\ Adnan Fadhil Khaleel \\ Assistant Professor, Director of Research and Strategic Studies \\ Lebanese French University, Iraq
}

\begin{abstract}
This paper investigates the quality of work life variables of educators in Lebanese French university Erbil Kurdistan region of Iraq. This research study highlights the quality of work life of educators under various dimensions. New Challenges can be faced with educator's nature of job role, work environment, Career Growth and Development, General Well-Being in achieving organizational goals. This study helps the educators to know the level of perception towards QWL and to enhance the same by the educational administrators. Quality of Work Life is the essential concept of favorable situations in a working environment. The Quality of Work Life facilitates employee's training opportunities, job satisfaction and working conditions. A better Quality of Work Life improves the growth of the employee's along with the organization growth. The universe of the study includes 4 colleges educators located within the Lebanese French university campus, i.e., college of engineering and sciences, college of education and languages, college of law and international relations and college of administration and economics. A sample of 50 respondents was collected from the universe. The collected data after being coded were analyzed using Statistical Package for Social sciences Research (SPSS) and various statistical tests were applied based on hypotheses and matching variables. It shows Quality of Work Life of Lebanese French University educators is in high level..
\end{abstract}

Keywords: Quality of Work Life, University Educators, Perception.

Cite this Article: Dr Kiran Das Naik Eslavath and Adnan Fadhil Khaleel, Quality of work Life of Educators in Lebanese French University, International Journal of Management, 10 (1), 2019, pp. 65-82.

http://iaeme.com/Home/issue/IJM?Volume=10\&Issue=1

\section{INTRODUCTION}

Quality of work life (QWL) refers to how an individual perceives his or her work life. It encompasses various aspects of work life, i.e., educator's nature of job role, work environment, Career Growth and Development, General Well- Being. Thus it is a 
multifaceted concept implying concern for the members of the university irrespective of the level they belong to. It is a continuous process of changing and improving the work climate so that the interface of people, technology and university makes for a more satisfying work experience for educators and gives desired outcomes for the organization. Although a good QWL helps all organizations to increase their performance/productivity irrespective of the sector they belong to, yet for the organizations in the service sector, it is more important because performance of the service organization is highly person-centric. A higher education institution is one such organization and the purpose of such institution is to provide relevant, accessible and quality education in cost effective manner. Performance of institutions in higher education is greatly dependent on the performance of teachers. A teacher is an instrument of transforming human resources into human capital. Teachers should experience high levels of quality of work life in order to realize their full potential and become an asset to the institution. Many researchers have explored QWL perceived by academia and its effects on their motivational level, leadership behaviour, and labour turnover.

\section{REVIEW OF RELATED LITERATURE}

Rochita Ganguly (2010) examined the QWL of university employees and the relationship between quality of work life and job satisfaction. The researcher was very careful in data collection. She considered literate and experienced persons who understand the significance of questioner and fill up the data correctly. She designed the questioner in Bengali, a regional language of employee for better understanding and thought flow. The results indicated that the employees are not happy with the degree of autonomy, personal growth and superior support. The employees were not satisfied with their job and unhappy with QWL of university.

D. Kumar and J.M. Deo (2011) did a study to measure the effect of stress on quality of work life of college teachers. They took 100 college teachers of universities of Bihar and Jharkhand and studied their different perception of quality of work life. Findings exposed that junior teachers had more stress than senior teachers. As well as female teachers were feeling more stress in their job in comparison to male teachers.

Ayesha Tabassumb (2012) investigated QWL of employees in the private universities of Bangladesh. She designed a 5-point Likert-scale structured questionnaire and collected the data from the 72 fulltime faculty members among 11 private universities. She analyzed the dimensions of quality of work life and its relationship with job satisfaction. This study concluded that there is positive relationship between the dimensions of QWL and job satisfaction. This study suggested to the management of the institutions that the policies designed in such a way that QWL issues should be concerned. An improved QWL provides a higher level of job satisfaction which in turn reduce faculty member turnover rate.

Seema Arif and Maryam Ilyas (2013) focused on quality of work life of private universities in Lahore, Pakistan. They explored various dimensions of quality of work life which affect life and the attitude of teachers. This quantitative study took 360 members of university and analyzes their perception of QWL. This study also investigated the QWL effects on employee commitment, engagement, job involvement and reputation of the university. This research suggested that the perceived value of work, work climate, work-life balance and satisfaction are the main factors which shaped the work attitude and also improve employees work life.

Jain Bindu and Swami Yashik(2014) in their study divulged that QWL in Indian academic sector is of low level. A planned change in the working environment is required to improve QWL in academic sector. Training, redesign of work, workshops for knowledge enhancement and personal growth, valuable participation in decision making, modification in promotion 
scheme etc. are some of the ways through which we can improve QWL. Improved QWL is beneficial for both the employee and institute so it's the mutual responsibility of the two. QWL of teachers at academic sector is below satisfaction and required attention and implementation of effective measures to improvement it. The major issues regarding QWL in academic sector are: i. Avenues for growth and development not satisfactory. ii. Promotional aspects are not satisfactory. iii. Teacher's participation in decision making is below satisfaction. iv. Job security is there but Job satisfaction is missing. v. Job involvement is lacking. Solutions: i. the level and number of designation regarding faculty should be increased and it should be same at college and university level. ii. There must be transparency and decisive role of teachers in decision making bodies of institution since teachers are not only the part parcel the institution, but also the important instrument in the implementation of different policies, rules and regulations. iii. Autonomy of the institution should be maintained with respect to its various dimensions such as recruitment, selection, framing of general polices, rules regulation etc. iv. Regular orientation/refresher courses, workshops, seminar, symposium etc. should be organized for teachers up gradation on current trends, methods, strategies, pedagogy of education. v. "Personality assessment test" for selection of new faculty should be rigorously conducted. vi. The administration should organize health related programmes for teachers in order to provide them better QWL.

\section{RESEARCH METHODOLOGY}

\subsection{Statement of the Problem}

The present study deals with the quality of wok life of educators in Lebanese French University. For evaluating the quality of wok life of educators, the researcher has chosen to study at, Lebanese French University. The study assumes assessment of Nature of job, work environment, communication, career growth and development and general wellbeing of the educators in Lebanese French University. Therefore, the research problem has been stated as the quality of wok life of educators in Lebanese French University.

\subsection{Research Gap of the Study}

Even though there are many research papers have been published on quality of work life. But there are no studies available in particularly on quality of work life of educators in Lebanese French University. So the researcher made an attempt to fill the research gap for studying entitled the quality of wok life of educators in Lebanese French University.

\subsection{Scope of the Study}

The study is to know the opinions of the respondents about the quality of work life of the educators in Lebanese French University. The scope of the study covered the areas of, Nature of job, work environment, communication, career growth and development and general wellbeing of the educators in Lebanese French University.

\subsection{Objectives of the study}

1. To study the nature of job of the Educators in LFU

2. To analyze the work environment of the educators in LFU

3. To survey how the educators feel about the communication in LFU

4. To examine the career growth and development of educators in LFU

5. To evaluate the General well-being of the Educators in LFU 


\subsection{Hypothesis}

A hypothesis is an assumption to be tested. The statistical testing of hypothesis is the most important technique in statistical inference. In attempting to reach decisions, it is used to make assumptions about the population involved. Such assumptions which may or may not be true are called statistical hypothesis and in general statement about the probability distribution of the population. The hypothesis is made about the parameter but the only facts available to estimate the true parameter are those provided by a sample. If the sample statistics differ from hypothesis made about the population parameter, a decision must be made as to whether or not this difference is significant, if it is to be rejected if not it must be accepted.

Ho: there is no significant relationship between the quality of work life variables and Age.

$\mathrm{H} 1$ : there is a significant relationship between quality of work life variables and Age Ho: there is no significant relationship between quality of work life variables and marital status

$\mathrm{H} 2$ : there is a significant relationship between quality of work life variables and marital status

Ho: there is no significant relationship between quality of work life variables and Educational qualifications

H3: there is a significant relationship between quality of work life variables and Educational qualifications

Ho: there is no significant relationship between quality of work life variables and position in the university

H4: there is a significant relationship between quality of work life variables and position in the university

Ho: there is no significant relationship between quality of work life variables and teaching Experience

H5: there is a significant relationship between quality of work life variables and teaching Experience

\subsection{Methodology of the Study}

Methodology of the study is a way to systematically solve the research problem. Application of appropriate methods and adoption of scientific procedure is essential of systematic enquiry. The present study uses different methods to analyze the data.

\subsection{Study Area}

The study area covers the quality of work life of the educators in Lebanese French University 2018-2019.

\subsection{Method of the study}

Application of appropriate method and adoption of scientific procedure is essential for any systematic enquiry. This has an important bearing on the collection of reliable and accurate information as well as on the outcome of the study. The present study uses a survey method.

\subsection{Sampling Method and Sample Size}

The researcher has used simple random sampling technique for the study. The universe and sample size of the study is 65 . 
The universe constitutes the educators of Lebanese French University. The total universe of the organization is 65 employees of various departments. The sample size taken from the universe for the study is $76 \%$ i.e. 50 respondents.

\section{DATA COLLECTION}

The data has been collected from employees of Lebanese French University. On the basis of both primary and secondary data.

\subsection{Primary Data}

To fulfill the objectives and to test the hypothesis, primary data is collected from the employees by using self-administered questionnaires.

\subsection{Questionnaire}

The questionnaire is often used as observational device for collecting personal data and opinion it provides a way to collect personal information from respondents that may not be readily obtainable using other methods. The instrument used under study has 25 questions which were grouped into five variables. The questionnaire is divided into two. The first part is demographic profile and the second part is Quality of work life which contains 5 variables i.e., Nature of job, work environment, communication, career growth and development and general wellbeing. Under each variable, there are sub-variables which have five statements each. Questionnaire was framed in the Likert-5-point scale.

\subsection{Processing of the data}

The study quality of work life of educators in Lebanese French University is processed through the qualitative and quantitative of the data.

\subsection{Qualitative Data}

Qualitative data is extremely varied in nature. It includes virtually any information that can be captured that is not numerical in nature. The data was collected through structured questionnaires.

\subsection{Quantitative Data}

Quantitative methods emphasize objective measurements and the statistical, mathematical or numerical analysis of data collected through questionnaires. Quantitative research focuses on gathering numerical data and generalizing it across groups of people or to explain a particular phenomenon.

\subsection{Statistical Tools}

For this study the researcher has used the Simple Frequency Distribution followed by Descriptive Statistics - Mean, Standard Deviation, and One-Way ANOVA Test.

Part-1 Personal Data of the educators in Lebanese French University

Table 1.1 Age of the respondents

\begin{tabular}{|c|c|c|c|c|c|}
\hline SI.No & Age in years & Frequency & Percent & Valid Percent & $\begin{array}{c}\text { Cumulative } \\
\text { Percent \% }\end{array}$ \\
\hline 1 & Below 30 & 4 & $8 \%$ & 8 & 8 \\
\hline 2 & $30-40$ & 33 & $66 \%$ & 66 & 74 \\
\hline 3 & $40-50$ & 7 & $14 \%$ & 14 & 80 \\
\hline 4 & Above & 6 & $12 \%$ & 12 & 26 \\
\hline & Total & 50 & 100 & 100 & 100 \\
\hline
\end{tabular}


The table-1.1. Examines the Age of the respondents. The total majority $66 \%$ of respondents are between 30-40 years of age, 14\% of respondents are between, $40-50,12 \%$ of respondents are above 50 years of age and only $8 \%$ of respondents are Below 30 years of age. The Lebanese French University has the highest majority of 30-40 years of age group educators.

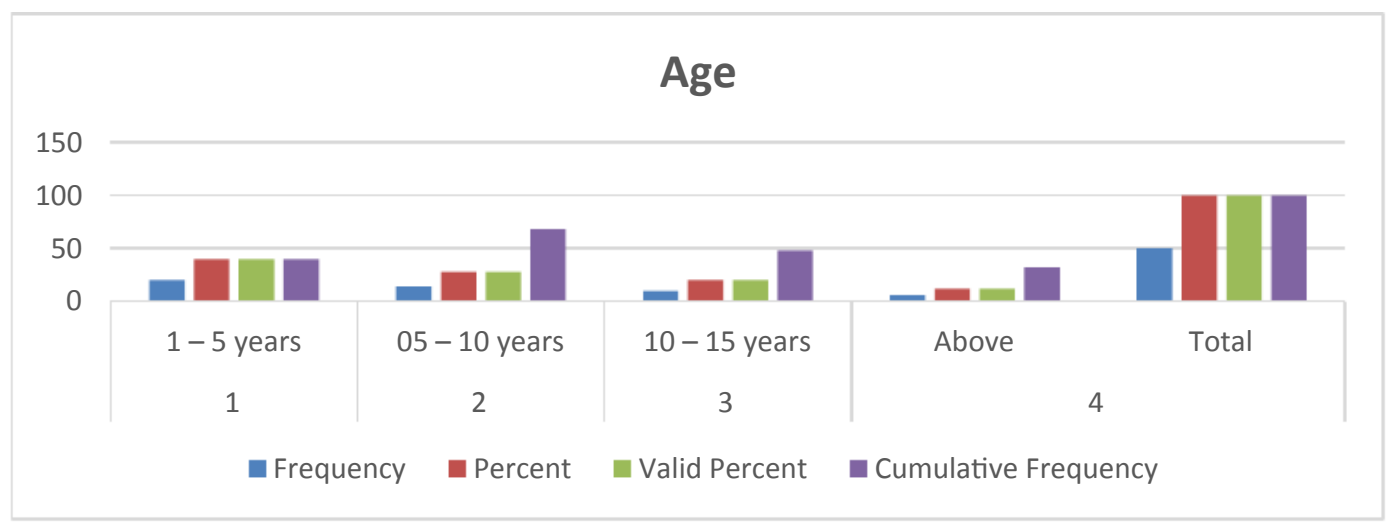

Table 1.2 marital status of the respondents

\begin{tabular}{|c|c|c|c|c|c|}
\hline SI.No & Marital Status & Frequency & Percent & Valid Percent & $\begin{array}{c}\text { Cumulative } \\
\text { percent \% }\end{array}$ \\
\hline 1 & Single & 10 & 20 & 20 & 20 \\
\hline 2 & Married & 40 & 80 & 80 & 100 \\
\hline & Total & 50 & 100 & 100 & 100 \\
\hline
\end{tabular}

The table-1.2. Exemplifies the Marital status of the respondents. The total majority $80 \%$ of respondents are married, $20 \%$ of respondents are unmarried. The Lebanese French University has the highest majority of $80 \%$ are married educators.

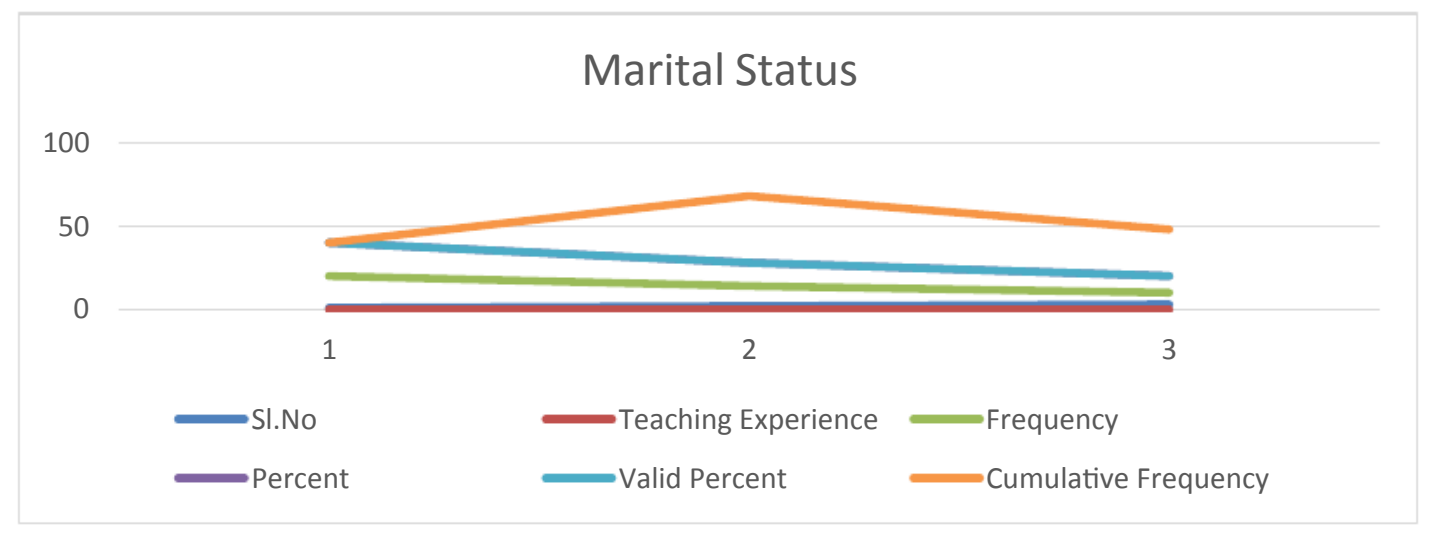

Table 1.3 Educational Qualifications of the respondents

\begin{tabular}{|c|c|c|c|c|c|}
\hline SI.No & $\begin{array}{c}\text { Educational } \\
\text { Qualifications }\end{array}$ & Frequency & Percent & Valid Percent & $\begin{array}{c}\text { Cumulative } \\
\text { percent \% }\end{array}$ \\
\hline 1 & Masters & 28 & 56 & 56 & 56 \\
\hline 2 & Doctorate & 22 & 44 & 44 & 100 \\
\hline 3 & Above & 0 & 0 & 0 & 44 \\
\hline & Total & 50 & 100 & 100 & 100 \\
\hline
\end{tabular}

The table-1.3. Reviews the Educational qualifications of the respondents. The total majority $56 \%$ of respondents are completed master's degree, $44 \%$ of respondents are 
completed their Doctoral Degree. The Lebanese French University has the highest majority of $56 \%$ are completed master's degree educators.

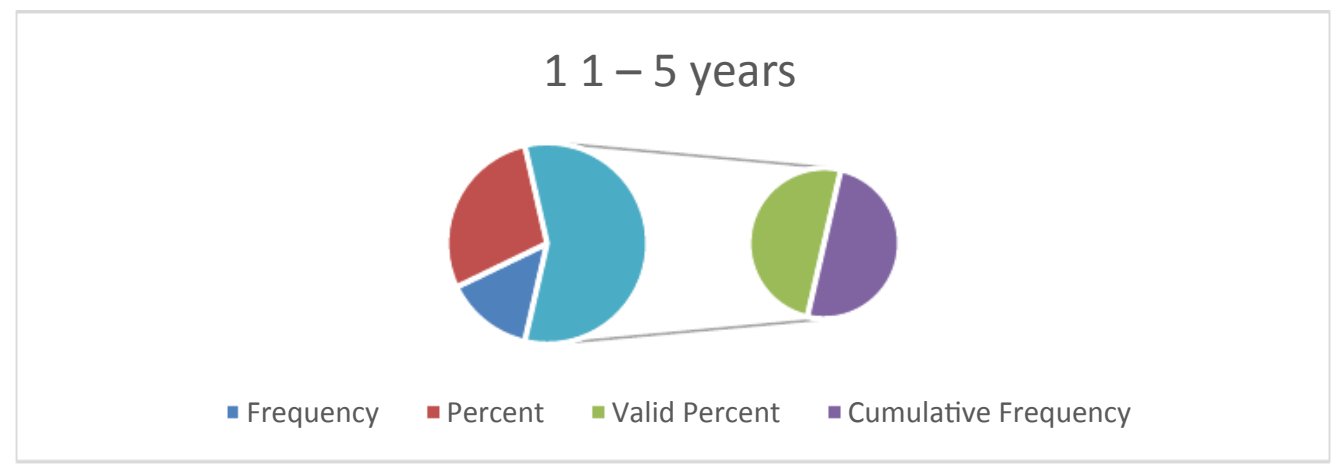

Table 1.4 Positon in the University of the respondents

\begin{tabular}{|c|c|c|c|c|c|}
\hline SI.No & $\begin{array}{c}\text { Position in } \\
\text { University }\end{array}$ & Frequency & Percent & Valid Percent & $\begin{array}{c}\text { Cumulative } \\
\text { percent \% }\end{array}$ \\
\hline 1 & Professor & 5 & 10 & 10 & 10 \\
\hline 2 & $\begin{array}{c}\text { Associate } \\
\text { professor }\end{array}$ & 4 & 8 & 8 & 18 \\
\hline 3 & $\begin{array}{c}\text { Assistant } \\
\text { professor }\end{array}$ & 12 & 24 & 24 & 30 \\
\hline 4 & Lecturer & 15 & 30 & 30 & 54 \\
\hline 5 & $\begin{array}{c}\text { Assistant } \\
\text { lecturer }\end{array}$ & 14 & 28 & 28 & 58 \\
\hline & Total & 50 & 100 & 100 & 100 \\
\hline
\end{tabular}

The table-1.4. Depicts the designation of the respondents. The total majority $30 \%$ of respondents are Lecturers, $28 \%$ of respondents are Assistant lecturers, $24 \%$ of respondents are Assistant Professors and 10\% of respondents are Professors, $8 \%$ of the respondents are associate professors. The Lebanese French university has the highest majority of $30 \%$ are lecturers.

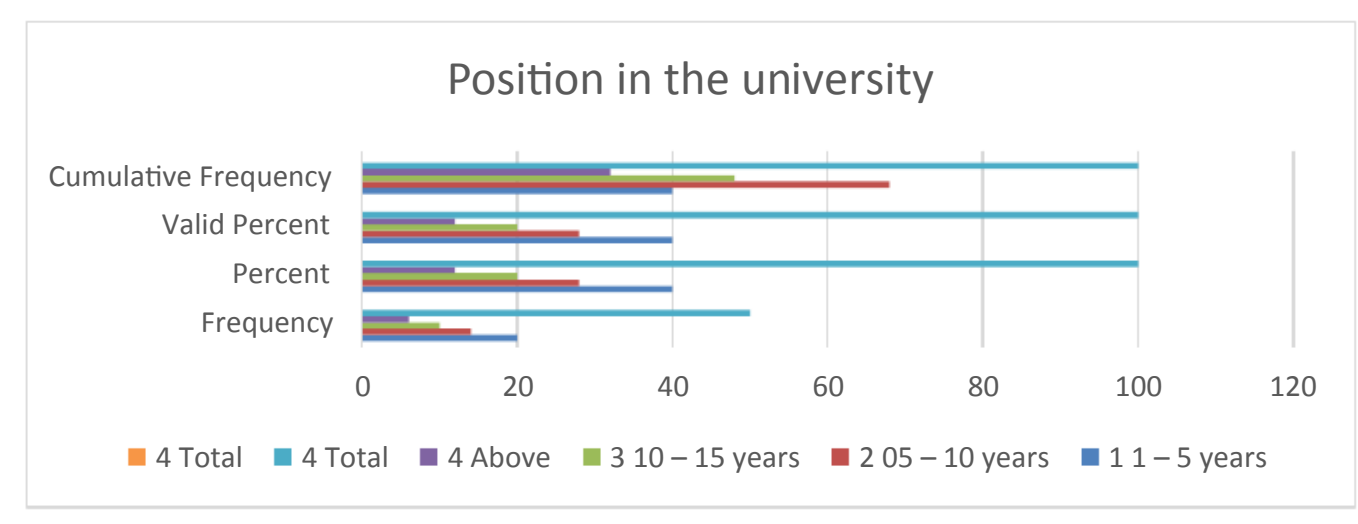

Table 1.5 Teaching Experience of the respondents

\begin{tabular}{|c|c|c|c|c|c|}
\hline SI.No & $\begin{array}{c}\text { Teaching } \\
\text { Experience }\end{array}$ & Frequency & Percent & Valid Percent & $\begin{array}{c}\text { Cumulative } \\
\text { Percent \% }\end{array}$ \\
\hline 1 & $0-4$ years & 12 & 20 & 20 & 20 \\
\hline 2 & $04-8$ years & 17 & 34 & 34 & 54 \\
\hline 3 & $09-15$ years & 16 & 32 & 32 & 86 \\
\hline 4 & $15 \&$ Above & 6 & 12 & 12 & 98 \\
\hline & Total & 50 & 100 & 100 & 100 \\
\hline
\end{tabular}


The table-1.5. Demonstrates the Teaching experience of the respondents. The total majority $20 \%$ of respondents are having 0-4 years of teaching Experience, $34 \%$ of respondents are having between 4-08 years of teaching experience, $32 \%$ of respondents are having 09-15 years of teaching experience and only $12 \%$ of respondents are having $15 \&$ above years of teaching experience. The Lebanese French University has the highest majority of $40 \%$ of respondents are having 1-5 years of teaching Experienced educators.

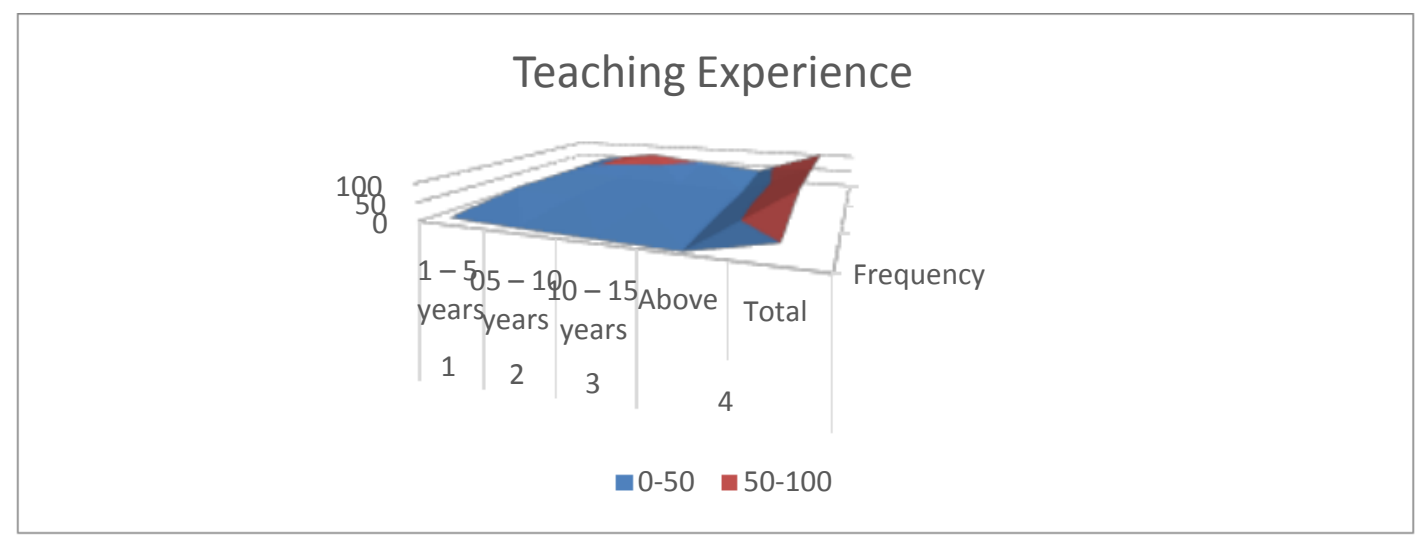

Descriptive Statistics of Quality of work life Variables

Table 1.6 Descriptive statistics for Nature of Job

\begin{tabular}{|c|c|c|c|c|}
\hline SI no & Nature of Job & Mean & Std. Deviation & Rank \\
\hline 1 & I have been placed in the job that I like very much. & 4.54 & 0.50346 & 1 \\
\hline 2 & The job is challenging and stimulating on. & 4.16 & 0.71027 & 4 \\
\hline 3 & I am clear what is expected from me in my role. & 4.42 & 0.64175 & 2 \\
\hline 4 & $\begin{array}{c}\text { This organization provides me necessary authorities to } \\
\text { carry out the job effectively. }\end{array}$ & 4.06 & 0.89008 & 5 \\
\hline 5 & I am satisfied with the title and nature of work. & 4.22 & 0.76372 & 3 \\
\hline
\end{tabular}

The table 1.6. Demonstrates the mean, standard deviation, skewness and kurtosis for Nature of Job. The highest mean value is 4.54 for the respondent have been placed in the job that they like very much. The lowest mean value is 4.06 and the highest standard deviation is 0.89008 the respondents feel that this organization provides me necessary authorities to carry out the job effectively. The lowest standard deviation is 0.50346 that the respondents are saying that they have been placed in the job that like very much. Across the observations, the descriptive statistics for nature of job depicts that the majority of the respondents are Agree in opinion with minimum variation.

Table 1.7 Descriptive Statistics for Work Environment

\begin{tabular}{|c|c|l|l|l|}
\hline Sl no & Work Environment & Mean & Std. Deviation & Rank \\
\hline 1 & $\begin{array}{c}\text { This university provides necessary tools and equipment to } \\
\text { perform the job well. }\end{array}$ & 4.02 & 0.89191 & 2 \\
\hline 2 & I find my working hours are flexible in this university. & 3.38 & 1.2599 & 5 \\
\hline 3 & My university has a good and safe environment. & 4.3 & 0.70711 & 1 \\
\hline 4 & I am not overloaded with work to do. & 3.52 & 1.19932 & 4 \\
\hline 5 & This university is having canteen facilities to employees. & 3.66 & 0.96065 & 3 \\
\hline
\end{tabular}

The table 1.7. Explains the mean, standard deviation, skewness and kurtosis for work environment. The highest mean value is 4.3 the respondent opinioned that the university has a good and safe environment. The lowest mean value is 3.38. And the highest standard deviation is 1.2599 the find their working hours are flexible in this university. The lowest 
standard deviation is 0.70711 that the respondents opinioned that the university has a good and safe environment. Across the observations, the descriptive statistics for work environment depicts that the majority of the respondents are Strongly Agree in opinion with minimum variation.

Table 1.8 Descriptive Statistics for Communication

\begin{tabular}{|c|c|c|c|c|}
\hline SI no. & Communication & Mean & Std. Deviation & Rank \\
\hline 1 & $\begin{array}{c}\text { Administration in this university encourage two-way } \\
\text { communication. }\end{array}$ & 3.92 & 1.14 & 2 \\
\hline 2 & $\begin{array}{c}\text { The rules and regulations of the university are clearly } \\
\text { communicated to us. }\end{array}$ & 3.9 & 0.86307 & 3 \\
\hline 3 & Communication across the university is effective. & 3.82 & 1.00387 & 4 \\
\hline 4 & $\begin{array}{c}\text { I receive timely information to help me do my job } \\
\text { well. }\end{array}$ & 3.8 & 0.90351 & 5 \\
\hline 5 & The vision and goal of the university are clearly \\
communicated to us. & 4.02 & 0.714 & 1 \\
\hline
\end{tabular}

The table 1.8. Explains the mean, standard deviation, skewness and kurtosis for Communication. The highest mean value is 4.02 the respondent opinioned that the vision and goal of the university are clearly communicated to us. The lowest mean value is 3.8 . And the highest standard deviation is 1.14 , the find Administration in this university encourage twoway communication. The lowest standard deviation is 0.714 that the respondents opinioned that the vision and goal of the university are clearly communicated to us. Across the observations, the descriptive statistics for communication depicts that the majority of the respondents are Strongly Agree in opinion with minimum variation.

Table 1.9 Descriptive Statistics for Career Growth and Development

\begin{tabular}{|c|c|c|c|c|}
\hline SI no. & Career Growth and Development & Mean & Std. Deviation & Rank \\
\hline 1 & $\begin{array}{c}\text { This university provides necessary } \\
\text { teaching orientation classes to the faculty } \\
\text { to improve the performance of employees }\end{array}$ & 4.02 & 0.68482 & 3 \\
\hline 2 & $\begin{array}{c}\text { I visualize good prospects for growth and } \\
\text { development in this university }\end{array}$ & 4.18 & 0.77433 & 1 \\
\hline 3 & $\begin{array}{c}\text { Promotion and other benefits are given to } \\
\text { the employees purely on the basis of } \\
\text { Employees performance and contribution. }\end{array}$ & 3.76 & 0.87037 & 5 \\
\hline 4 & $\begin{array}{c}\text { This university promote equal } \\
\text { opportunities to the employees for growth } \\
\text { and development. }\end{array}$ & 3.86 & 0.88086 & 4 \\
\hline 5 & $\begin{array}{c}\text { I am satisfied with the opportunities } \\
\text { given by the organization to develop my } \\
\text { career. }\end{array}$ & 4.1 & 0.81441 & 2 \\
\hline
\end{tabular}

The table 1.9. Explains the mean, standard deviation, skewness and kurtosis for Communication. The highest mean value is 4.18 the respondent opinioned that they visualize good prospects for growth and development in this university. The lowest mean value is 3.76. And the highest standard deviation is 0.88086 , the find that this University promote equal opportunities to the employees for growth and development. The lowest standard deviation is 0.68482 that this university provides necessary teaching orientation classes to the faculty to improve the performance of employees. Across the observations, the descriptive statistics for 
career growth and development depicts that the majority of the respondents are Strongly Agree and neutral opinion with minimum variation.

Table 1.10 Descriptive Statistics for General Well- Being

\begin{tabular}{|c|c|c|c|c|}
\hline SI no. & General Well- Being & Mean & Std. Deviation & Rank \\
\hline 1 & This university has appropriate family- friendly \\
policies. & 4.14 & 0.72871 & 1 \\
\hline 2 & $\begin{array}{c}\text { This university promotes health and wellbeing of } \\
\text { employees. }\end{array}$ & 3.88 & 0.82413 & 5 \\
\hline 3 & $\begin{array}{c}\text { My university policies are quite supportive of } \\
\text { working faculty in this university. }\end{array}$ & 3.98 & 0.79514 & 4 \\
\hline 4 & $\begin{array}{c}\text { I never faced any physical or psychological } \\
\text { violence in the workplace. }\end{array}$ & 4.02 & 1.15157 & 3 \\
\hline 5 & $\begin{array}{c}\text { This university takes special efforts for ensuring } \\
\text { the safety of the employees. }\end{array}$ & 4.04 & 0.85619 & 2 \\
\hline
\end{tabular}

The table 1.10 General Well-Being. Explains the mean, standard deviation, skewness and kurtosis for Communication. The highest mean value is 4.14 the respondent opinioned this university has appropriate family- friendly policies. The lowest mean value is 3.88 . And the highest standard deviation is 1.15157 , the find that they never faced any physical or psychological violence in the workplace. The lowest standard deviation is 0.72871 that this university this university has appropriate family- friendly policies. Across the observations, the descriptive statistics for general well-Being depicts that the majority of the respondents are Agree and neutral opinion with minimum variation.

Testing Of One Way Anova between Demographic Profiles and Quality of Work Life Variables

Table No 1.11 One-Way ANOVA for Age and QWL Variables

\begin{tabular}{|c|c|c|c|c|c|c|}
\hline & Between Groups & $\begin{array}{c}\text { Sum of Squares } \\
.164\end{array}$ & $\begin{array}{c}\text { df } \\
3\end{array}$ & $\begin{array}{c}\text { Mean Square } \\
.055\end{array}$ & $\begin{array}{c}\mathbf{F} \\
.266\end{array}$ & $\begin{array}{l}\text { Sig. } \\
.850\end{array}$ \\
\hline \multirow[t]{2}{*}{ Nature of Job } & Within Groups & 9.436 & 46 & .205 & & \\
\hline & Total & 9.600 & 49 & & & \\
\hline \multirow{3}{*}{ Work Environment } & Between Groups & .350 & 3 & .117 & .232 & .874 \\
\hline & Within Groups & 23.141 & 46 & .503 & & \\
\hline & Total & 23.491 & 49 & & & \\
\hline \multirow{3}{*}{ Communication } & Between Groups & .709 & 3 & .236 & .410 & .747 \\
\hline & Within Groups & 26.508 & 46 & .576 & & \\
\hline & Total & 27.217 & 49 & & & \\
\hline \multirow{3}{*}{$\begin{array}{l}\text { Career Growth and } \\
\text { Development }\end{array}$} & Between Groups & .527 & 3 & .176 & .470 & .705 \\
\hline & Within Groups & 17.220 & 46 & .374 & & \\
\hline & Total & 17.747 & 49 & & & \\
\hline \multirow{3}{*}{ General Well-being } & Between Groups & .902 & 3 & .301 & .624 & .603 \\
\hline & Within Groups & 22.171 & 46 & .482 & & \\
\hline & Total & 23.073 & 49 & & & \\
\hline
\end{tabular}

Ho: there is no significant difference between the quality of work life variables and Age

The table-1.11. One-Way ANOVA Test for QWL variables and Age of the respondents reveals: 
1. The Nature of job - The null hypothesis $\left(\mathrm{H}_{0}\right)$ is not rejected. Hence, there is no statistically significant difference in the mean opinion on Nature of with respect to Age $F_{(3,46)}=.266, p=.850>0.05$. It is concluded that the respondents of Lebanese French University are of same opinion with respect to their Age.

2. Work Environment - The null hypothesis $\left(\mathrm{H}_{0}\right)$ is not rejected. Hence, there is no statistically significant difference in the mean opinion on Work Environment with respect to Age $\mathrm{F}(3,46)=.232, \mathrm{p}=.874>0.05$. It is concluded that the respondents of Lebanese French University are of same opinion with respect to their Age.

3. Communication - The null hypothesis $\left(\mathrm{H}_{0}\right)$ is not rejected. Hence, there is statistically significant difference in the mean opinion on Communication with respect to Age $\mathrm{F}$ (3, $46)=.410, p=.747>0.05$. It is concluded that the respondents of Lebanese French University are of same opinion with respect to their Age.

4. Career Growth and Development - The null hypothesis $\left(\mathrm{H}_{0}\right)$ is not rejected. Hence, there is no statistically significant difference in the mean opinion on Career Growth and Development with respect to Age $F(3,46)=.470, p=.705>0.05$. It is concluded that the respondents of Lebanese French University are of same opinion with respect to their Age.

5. General Well-being - The null hypothesis $\left(\mathrm{H}_{0}\right)$ is not rejected. Hence, there is no statistically significant difference in the mean opinion on General Well- Being with respect to Age $\mathrm{F}(3,46)=.624, \mathrm{p}=.603>0.05$. It is concluded that the respondents of Lebanese French University are of same opinion with respect to their Age.

Table No 1.12 One-Way ANOVA for Marital status and QWL Variables

\begin{tabular}{|c|c|c|c|c|c|c|}
\hline & & Sum of Squares & df & Mean Square & $\mathbf{F}$ & Sig. \\
\hline \multirow{3}{*}{ Nature of Job } & Between Groups & .005 & 1 & .005 & .025 & .875 \\
\hline & Within Groups & 9.595 & 48 & .200 & & \\
\hline & Total & 9.600 & 49 & & & \\
\hline \multirow{3}{*}{ Work Environment } & Between Groups & .135 & 1 & .135 & .278 & .601 \\
\hline & Within Groups & 23.356 & 48 & .487 & & \\
\hline & Total & 23.491 & 49 & & & \\
\hline \multirow{3}{*}{ Communication } & Between Groups & .157 & 1 & .157 & .278 & .600 \\
\hline & Within Groups & 27.060 & 48 & .564 & & \\
\hline & Total & 27.217 & 49 & & & \\
\hline \multirow{3}{*}{$\begin{array}{l}\text { Career Growth and } \\
\text { Development }\end{array}$} & Between Groups & .051 & 1 & .051 & .139 & .711 \\
\hline & Within Groups & 17.696 & 48 & .369 & & \\
\hline & Total & 17.747 & 49 & & & \\
\hline \multirow{3}{*}{ General Well-being } & Between Groups & .002 & 1 & .002 & .004 & .951 \\
\hline & Within Groups & 23.071 & 48 & .481 & & \\
\hline & Total & 23.073 & 49 & & & \\
\hline
\end{tabular}

Ho: there is no significant difference between the quality of work life variables and Marital Status.

The table-1.12. One-Way ANOVA Test for QWL variables and Marital status of the respondents reveals:

1. The Nature of job - The null hypothesis $\left(\mathrm{H}_{0}\right)$ is not rejected. Hence, there is no statistically significant difference in the mean opinion on Nature of job with respect to 
Marital Status $F_{(1,48)}=.025, p=.875>0.05$. It is concluded that the respondents of Lebanese French University are of same opinion with respect to their Marital Status.

2. Work Environment - The null hypothesis $\left(\mathrm{H}_{0}\right)$ is not rejected. Hence, there is no statistically significant difference in the mean opinion on Work Environment with respect to Marital Status $F_{(1,48)}=.278, p=.601>0.05$. It is concluded that the respondents of Lebanese French University are of same opinion with respect to their Marital Status.

3. Communication - The null hypothesis $\left(\mathrm{H}_{0}\right)$ is not rejected. Hence, there is statistically significant difference in the mean opinion on Communication with respect to Marital Status $\mathrm{F}_{(1,48)}=.278, \mathrm{p}=.600>0.05$. It is concluded that the respondents of Lebanese French University are of same opinion with respect to their Marital Status.

4. Career Growth and Development - The null hypothesis $\left(\mathrm{H}_{0}\right)$ is not rejected. Hence, there is no statistically significant difference in the mean opinion on Career Growth and Development with respect to Marital Status $\mathrm{F}_{(1,48)}=.139, \mathrm{p}=.711>0.05$. It is concluded that the respondents of South Central Railway are of same opinion with respect to their Marital Status.

5. General Well-being - The null hypothesis $\left(\mathrm{H}_{0}\right)$ is not rejected. Hence, there is no statistically significant difference in the mean opinion on General well-being with respect to Marital Status $F_{(1,48)}=.004, p=.951>0.05$. It is concluded that the respondents of Lebanese French University are of same opinion with respect to their Marital Status.

Table 1.13 One-Way ANOVA for Educational Qualifications and QWL Variables

\begin{tabular}{|c|c|c|c|c|c|c|}
\hline & & Sum of Squares & df & Mean Square & $\mathbf{F}$ & Sig. \\
\hline \multirow{3}{*}{ Nature of Job } & Between Groups & .249 & 1 & .249 & 1.280 & .263 \\
\hline & Within Groups & 9.351 & 48 & .195 & & \\
\hline & Total & 9.600 & 49 & & & \\
\hline \multirow{3}{*}{ Work Environment } & Between Groups & 3.249 & 1 & 3.249 & 7.703 & .008 \\
\hline & Within Groups & 20.243 & 48 & .422 & & \\
\hline & Total & 23.491 & 49 & & & \\
\hline \multirow{3}{*}{ Communication } & Between Groups & 1.478 & 1 & 1.478 & 2.756 & .103 \\
\hline & Within Groups & 25.739 & 48 & .536 & & \\
\hline & Total & 27.217 & 49 & & & \\
\hline \multirow{3}{*}{$\begin{array}{l}\text { Career Growth and } \\
\text { Development }\end{array}$} & Between Groups & 2.150 & 1 & 2.150 & 6.618 & .013 \\
\hline & Within Groups & 15.597 & 48 & .325 & & \\
\hline & Total & 17.747 & 49 & & & \\
\hline \multirow{3}{*}{ General Well-being } & Between Groups & 1.117 & 1 & 1.117 & 2.441 & .125 \\
\hline & Within Groups & 21.956 & 48 & .457 & & \\
\hline & Total & 23.073 & 49 & & & \\
\hline
\end{tabular}

Ho: there is no significant difference between the quality of work life variables and Educational Qualifications.

The table-1.13. One-Way ANOVA Test for QWL variables and Educational Qualifications of the respondents reveals:

1. The Nature of job - The null hypothesis $\left(\mathrm{H}_{0}\right)$ is not rejected. Hence, there is no statistically significant difference in the mean opinion on Nature of job with respect to Educational Qualifications $\mathrm{F}_{(1,48)}=1.280, \mathrm{p}=.263>0.05$. It is concluded that the 
respondents of Lebanese French University are of same opinion with respect to their Educational Qualifications.

2. Work Environment - The null hypothesis $\left(\mathrm{H}_{0}\right)$ is rejected. Hence, there is a statistically significant difference in the mean opinion on Work Environment with respect to Educational Qualifications $\mathrm{F}_{(1,48)}=7.703, \mathrm{p}=.008<0.05$. It is concluded that the respondents of Lebanese French University are of different opinion with respect to their Educational Qualifications.

3. Communication - The null hypothesis $\left(\mathrm{H}_{0}\right)$ is not rejected. Hence, there is statistically significant difference in the mean opinion on Communication with respect to Educational Qualifications $\mathrm{F}_{(1,48)}=2.756, \mathrm{p}=.103>0.05$. It is concluded that the respondents of Lebanese French University are of same opinion with respect to their Educational Qualifications.

4. Career Growth and Development - The null hypothesis $\left(\mathrm{H}_{0}\right)$ is rejected. Hence, there is no statistically significant difference in the mean opinion on Career Growth and Development with respect to Educational Qualifications $\mathrm{F}_{(1,48)}=6.618, \mathrm{p}=.013<$ 0.05. It is concluded that the respondents of South Central Railway are of different opinion with respect to their Educational Qualifications.

5. General Well-being - The null hypothesis $\left(\mathrm{H}_{0}\right)$ is not rejected. Hence, there is no statistically significant difference in the mean opinion on General Well-being with

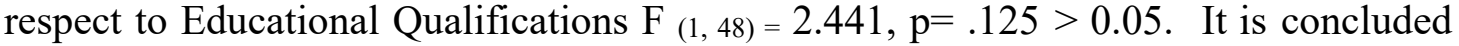
that the respondents of Lebanese French University are of same opinion with respect to their Educational Qualifications.

Table 1.14 One-Way ANOVA for Position in the university and QWL Variables

\begin{tabular}{|c|c|c|c|c|c|c|}
\hline & & Sum of Squares & df & Mean Square & $\mathbf{F}$ & Sig. \\
\hline \multirow{3}{*}{ Nature of Job } & Between Groups & .927 & 4 & .232 & 1.203 & .323 \\
\hline & Within Groups & 8.673 & 45 & .193 & & \\
\hline & Total & 9.600 & 49 & & & \\
\hline \multirow{3}{*}{ Work Environment } & Between Groups & 3.906 & 4 & .977 & 2.244 & .079 \\
\hline & Within Groups & 19.585 & 45 & .435 & & \\
\hline & Total & 23.491 & 49 & & & \\
\hline \multirow{3}{*}{ Communication } & Between Groups & 2.674 & 4 & .668 & 1.226 & .313 \\
\hline & Within Groups & 24.543 & 45 & .545 & & \\
\hline & Total & 27.217 & 49 & & & \\
\hline \multirow{3}{*}{$\begin{array}{l}\text { Career Growth and } \\
\text { Development }\end{array}$} & Between Groups & 3.986 & 4 & .997 & 3.259 & .020 \\
\hline & Within Groups & 13.761 & 45 & .306 & & \\
\hline & Total & 17.747 & 49 & & & \\
\hline \multirow{3}{*}{ General Well-being } & Between Groups & 4.548 & 4 & 1.137 & 2.762 & .039 \\
\hline & Within Groups & 18.525 & 45 & .412 & & \\
\hline & Total & 23.073 & 49 & & & \\
\hline
\end{tabular}

Ho: there is no significant difference between the quality of work life variables and Position in the University.

The table-1.14. One-Way ANOVA Test for QWL variables and Position in the University of the respondents reveals:

1. The Nature of job - The null hypothesis $\left(\mathrm{H}_{0}\right)$ is not rejected. Hence, there is no statistically significant difference in the mean opinion on Nature of job with respect to 
Position in the University $\mathrm{F}(4,45)=.1203, \mathrm{p}=.323>0.05$. It is concluded that the respondents of Lebanese French University are of same opinion with respect to their Position in the University.

2. Work Environment - The null hypothesis $\left(\mathrm{H}_{0}\right)$ is rejected. Hence, there is a statistically significant difference in the mean opinion on Work Environment with respect to Position in the University $F_{(4,45)}=2.244, p=.079<0.05$. It is concluded that the respondents of Lebanese French University are of different opinion with respect to their Position in the University.

3. Communication - The null hypothesis $\left(\mathrm{H}_{0}\right)$ is not rejected. Hence, there is statistically a significant difference in the mean opinion on Communication with respect to Position in the University us $\mathrm{F}_{(4,45)}=1.226, \mathrm{p}=.313>0.05$. It is concluded that the respondents of Lebanese French University are of same opinion with respect to their Position in the University.

4. Career Growth and Development - The null hypothesis $\left(\mathrm{H}_{0}\right)$ is rejected. Hence, there is a statistically significant difference in the mean opinion on Career Growth and Development with respect to Position in the University $F_{(4,45)}=3.259, p=.020<0.05$. It is concluded that the respondents of Lebanese French University are of different opinion with respect to their Position in the University.

5. General Well-being - The null hypothesis $\left(\mathrm{H}_{0}\right)$ is rejected. Hence, there is a statistically significant difference in the mean opinion on General well-being with

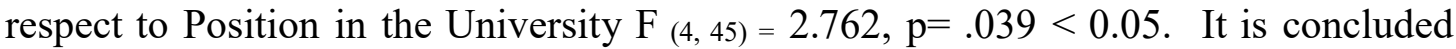
that the respondents of Lebanese French University are of different opinion with respect to their Position in the University.

Table 1.15 One-Way ANOVA for Experience in Teaching and QWL Variables

\begin{tabular}{|c|c|c|c|c|c|c|}
\hline & & Sum of Squares & df & Mean Square & $\mathbf{F}$ & Sig. \\
\hline \multirow{3}{*}{ Nature of Job } & Between Groups & .718 & 3 & .239 & 1.239 & .306 \\
\hline & Within Groups & 8.882 & 46 & .193 & & \\
\hline & Total & 9.600 & 49 & & & \\
\hline \multirow{3}{*}{ Work Environment } & Between Groups & 2.161 & 3 & .720 & 1.554 & .213 \\
\hline & Within Groups & 21.330 & 46 & .464 & & \\
\hline & Total & 23.491 & 49 & & & \\
\hline \multirow{3}{*}{ Communication } & Between Groups & 2.534 & 3 & .845 & 1.574 & .208 \\
\hline & Within Groups & 24.682 & 46 & .537 & & \\
\hline & Total & 27.217 & 49 & & & \\
\hline \multirow{3}{*}{$\begin{array}{l}\text { Career Growth and } \\
\text { Development }\end{array}$} & Between Groups & 2.154 & 3 & .718 & 2.118 & .111 \\
\hline & Within Groups & 15.594 & 46 & .339 & & \\
\hline & Total & 17.747 & 49 & & & \\
\hline \multirow{3}{*}{ General Well-being } & Between Groups & 3.153 & 3 & 1.051 & 2.427 & .077 \\
\hline & Within Groups & 19.920 & 46 & .433 & & \\
\hline & Total & 23.073 & 49 & & & \\
\hline
\end{tabular}

Ho: there is no significant difference between the quality of work life variables and Experience in teaching.

The table-1.15. One-Way ANOVA Test for QWL variables and Experience in teaching of the respondents reveals: 
1. The Nature of job - The null hypothesis $\left(\mathrm{H}_{0}\right)$ is not rejected. Hence, there is no statistically significant difference in the mean opinion on Nature of job with respect to Experience in teaching $\mathrm{F}_{(3,46)}=1.239, \mathrm{p}=.306>0.05$. It is concluded that the respondents of Lebanese French University are of same opinion with respect to their Experience in teaching.

2. Work Environment - The null hypothesis $\left(\mathrm{H}_{0}\right)$ is not rejected. Hence, there is no statistically significant difference in the mean opinion on Work Environment with respect to Experience in teaching $\mathrm{F}_{(3,46)}=1.554, \mathrm{p}=.213>0.05$. It is concluded that the respondents of Lebanese French University are of same opinion with respect to their Experience in teaching.

3. Communication - The null hypothesis $\left(\mathrm{H}_{0}\right)$ is not rejected. Hence, there is statistically significant difference in the mean opinion on Communication with respect to Experience in teaching $\mathrm{F}_{(3,46)}=1.574, \mathrm{p}=.208>0.05$. It is concluded that the respondents of Lebanese French University are of same opinion with respect to their Experience in teaching.

4. Career Growth and Development - The null hypothesis $\left(\mathrm{H}_{0}\right)$ is not rejected. Hence, there is no statistically significant difference in the mean opinion on Career Growth and Development with respect to Experience in teaching $F_{(3,46)}=2.118, p=.111>$ 0.05. It is concluded that the respondents of Lebanese French University are of same opinion with respect to their Experience in teaching.

5. General Well-being - The null hypothesis $\left(\mathrm{H}_{0}\right)$ is rejected. Hence, there is a statistically significant difference in the mean opinion on General well-being with respect to Experience in teaching $\mathrm{F}_{(3,46)}=2.427, \mathrm{p}=.077<0.05$. It is concluded that the respondents of Lebanese French University are of different opinion with respect to their Experience in teaching.

\section{FINDINGS}

\subsection{NATURE OF JOB}

Q1. Majority $56 \%$ of the respondents are Strongly Agreed and $44 \%$ are agreed that they placed in the job and they like it very much.

Q2. Majority 52\% of the respondents are agreed and 34\% are strongly agreed with job is challenging and stimulating on. $12 \%$ respondents are neutral and only $2 \%$ of the respondents are disagreed.

Q3. Majority $58 \%$ of the respondents are strongly agreed and $34 \%$ are agreed that they were clear what is expected from them in their job role. $8 \%$ respondents are neutral.

Q4. Majority $44 \%$ of the respondents are strongly agreed and $34 \%$ are agreed that the LFU providing them necessary authorities to carry out the job effectively. $16 \%$ respondents are neutral and only $6 \%$ of the respondents are disagreed.

Q5. Majority $46 \%$ of the respondents are agreed and 38\% are strongly agreed that the respondents were satisfied with the title and nature of work in LFU. $8 \%$ respondents are neutral and only $8 \%$ of the respondents are disagreed.

\subsubsection{Work environment}

Q6. Majority $50 \%$ of the respondents are agreed and 32\% are strongly agreed that LFU provides necessary tools and equipment to perform the job well. $14 \%$ respondents are neutral and only $4 \%$ of the respondents are disagreed. 
Q7. Majority $36 \%$ of the respondents are agreed and $26 \%$ are strongly agreed that university working hours are flexible in this university. $18 \%$ respondents are neutral and only $12 \%$ of the respondents are disagreed, and $8 \%$ of the respondents are strongly disagreed with the working hours in LFU.

Q8. Majority $38 \%$ of the respondents are strongly agreed and $34 \%$ are agreed that LFU has a good and safe environment. $14 \%$ respondents are neutral and only $14 \%$ of the respondents are strongly disagreed with the good and safe environment in LFU.

Q9. Majority $30 \%$ of the respondents are agreed and $28 \%$ are strongly agreed that the respondents are not overloaded with work to do. $20 \%$ respondents are neutral and only $16 \%$ of the respondents are disagreed, and $6 \%$ of the respondents are strongly disagreed and opined that they were overloaded with the work.

Q10. Majority $52 \%$ of the respondents are agreed and $18 \%$ are strongly agreed that LFU is having canteen facilities to employees. $14 \%$ respondents are neutral and $14 \%$ of the respondents are disagreed, and $2 \%$ of the respondents are strongly disagreed about the canteen facilities in LFU.

\subsubsection{Communication}

Q11. Majority $42 \%$ of the respondents are strongly agreed and $34 \%$ are agreed Administration in LFU encourage two-way communication. $8 \%$ respondents are neutral and $14 \%$ of the respondents are disagreed, and $2 \%$ of the respondents are strongly disagreed Administration in this university encourage two-way communication.

Q12. Majority $54 \%$ of the respondents are agreed and $26 \%$ are strongly agreed that the rules and regulations of the LFU are clearly communicated to the respondents. $12 \%$ respondents are neutral and $8 \%$ of the respondents are disagreed they opined that the rules and regulations of the LFU are not clearly communicated to them.

Q13. Majority $40 \%$ of the respondents are agreed and $32 \%$ are strongly agreed that Communication across the LFU is effective. $16 \%$ respondents are neutral and $12 \%$ of the respondents are disagreed that communication across the LFU is not effective.

Q14. Majority $50 \%$ of the respondents are agreed and $22 \%$ are strongly agreed that the respondents are receiving timely information to help them to do their job well. $16 \%$ respondents are neutral and $12 \%$ of the respondents are disagreed that they are not receiving timely information to help them to do their job well.

Q15. Majority $56 \%$ of the respondents are agreed and $28 \%$ are strongly agreed that the vision and goal of the LFU is clearly communicated to the respondents. $12 \%$ respondents are neutral and $4 \%$ of the respondents are disagreed that they vision and the goal of the LFU is not clearly communicated to the respondents.

\subsubsection{Career Growth and Development}

Q16. Majority $58 \%$ of the respondents are agreed and $24 \%$ are strongly agreed that LFU provides necessary teaching orientation classes to the faculty to improve the performance of educators. $16 \%$ respondents are neutral and $2 \%$ of the respondents are disagreed that they opined that LFU is not providing any necessary teaching orientation classes to the faculty to improve the performance of educators.

Q17. Majority $54 \%$ of the respondents are agreed and $36 \%$ are strongly agreed that the respondents visualize good prospects for growth and development in LFU. $8 \%$ respondents are neutral and $2 \%$ of the respondents are disagreed that they cannot visualize any good prospects for growth and development in LFU. 
Q18. Majority $50 \%$ of the respondents are agreed and $22 \%$ are strongly that Promotion and other benefits are given to the educators are purely on the basis of performance and contribution to LFU. $16 \%$ respondents are neutral and $12 \%$ of the respondents are disagreed that the Promotion and other benefits are not given to the educators are purely on the basis of performance and contribution to LFU.

Q19. Majority $46 \%$ of the respondents are agreed and $24 \%$ are strongly agreed that LFU promote equal opportunities to the educators for growth and development. $22 \%$ respondents are neutral and $8 \%$ of the respondents are disagreed that LFU is not promoting equal opportunities to the educators for growth and development.

Q20. Majority $52 \%$ of the respondents are agreed and $34 \%$ are strongly agreed that the respondents are satisfied with the opportunities given by the LFU to develop their career. 10 $\%$ respondents are neutral, $2 \%$ of the respondents are disagreed, and $2 \%$ of the respondents are strongly disagreed with the opportunities given by the LFU to develop their career.

\subsubsection{General Well- Being}

Q21. Majority $66 \%$ of the respondents are agreed and $28 \%$ are strongly agreed that LFU has appropriate family- friendly policies. $2 \%$ respondents are neutral, $2 \%$ of the respondents are disagreed, and $2 \%$ of the respondents are strongly disagreed that LFU has no appropriate family- friendly policies.

Q22. Majority $60 \%$ of the respondents are agreed and $18 \%$ are strongly agreed that LFU promotes health and wellbeing of educators. $16 \%$ respondents are neutral, $4 \%$ of the respondents are disagreed, and $2 \%$ of the respondents are strongly disagreed that LFU is not promoting health and wellbeing of educators.

Q23. Majority $66 \%$ of the respondents are agreed and $22 \%$ are strongly agreed that LFU policies are quite supportive of working faculty in LFU. $8 \%$ respondents are neutral, $4 \%$ of the respondents are disagreed, and that LFU policies are not quite supportive of working faculty in LFU.

Q24. Majority $46 \%$ of the respondents are strongly agreed and $30 \%$ are agreed that they never faced any physical or psychological violence in the workplace. $10 \%$ respondents are neutral, $10 \%$ of the respondents are disagreed, and $4 \%$ of the respondents are strongly disagreed that they faced physical or psychological violence in the workplace.

Q25. Majority $38 \%$ of the respondents are agreed and $36 \%$ are strongly agreed that LFU takes special efforts for ensuring the safety of the educators. $22 \%$ respondents are neutral, 4 $\%$ of the respondents are disagreed, and that LFU is not taking any special efforts for ensuring the safety of the educators.

\section{CONCLUSION}

QWL is the shared responsibility not only of the management and educators, but also by the society. To improve Quality of work life is first to identify and then try to satisfy employee's important needs through the QWL variables. Depending upon the situational requirements, management may select the relevant needs of the employee's to improve them with a short term plan. There is a significant association between quality of work life total and quality of life in teaching environment total. It shows QWL of university educators is in high level. According to this report, improved flexible working environment was found to be successful in LFU. According to traditional teachings, the workplace is a temple and work is worship. A planned change in the nature of the job, working environment, communication, career growth and development and General well-being of the educators is the need of the hour to improve QWL in LFU. Improved Flexible working environment can be an answer to the multifarious 
roles of the LFU educators. This research is to enhance the QWL of the Educators by integrating the task role and social role, such that the synergies are effectively obtained.

\section{REFERENCES}

[1] Ganguly, R. Quality of Work life and Job Satisfaction of a Group of University Employees, Asian Journal Of Management Research, 2010, pp 209-216.

[2] R. Vivekanandhan and Dr. R. Mohan Kumar, A Comparative Analysis of The Quality of Work Life of Teaching Faculty Members Of Government And Private Engineering Institutions In Chennai, International Journal of Advanced Research in Management (IJARM), Volume 5, Issue 4, July- August (2014), pp. 11-22

[3] Kumar, D., \& Deo, J., M., (2011). Stress and Work Life of College Teachers, Journal of Academy of Indian Academy of Applied Psychology, 37, 2011, 78- 85.

[4] Dr. Yogesh Deshpande and Mrs. Bhagyashri J Bhakane, A Comparative Study on Quality of Work Life Dimensions in Small Medium Enterprises \& Large-Scale Enterprises, International Journal of Management (IJM), Volume 6, Issue 5, May (2015), pp. 46-52

[5] Tabassum, A., Interrelations between Quality of Work Life Dimensions and Faculty Member Job Satisfaction in the Private Universities of Bangladesh, European Journal of Business and Management, 4(2),2012, pp 78-89.

[6] Khalid Imran1 and Dr. K.V.A. Balaji, A Comparative Survey of the Impact of Training and Development on Quality of Work Life of Employees Working in Private And Public Manufacturing Industries, International Journal of Mechanical Engineering And Technology (IJMET), Volume 5, Issue 9, September (2014), pp. 126-132.

[7] Arif S., \& Ilyas M., Quality of Work- life model for Teachers of Private Universities in Pakistan. Quality Assurance in Education, Emerald Group Publishing Limited. 21(3), 2013, pp 282-298.

[8] Bindu Jain and Swami Yashika, Quality of Work Life with Special Reference to Academic Sector, Research Journal of Management Sciences, Vol. 3(1),2014,pp 14-17.

[9] M. Surya Kumar and Dr. N. Shani, A Study on Quality of Work Life Among the Employees at Metro Engineering Private Limited, International Journal of Management (IJM), Volume 4, Issue 1, January- February (2013), pp. 01-05.

[10] Kothari, Publisher, Research Methodology, New Delhi, New Age International (P) Ltd.

[11] S. Aruna and Dr. V Seetha, A Study on Quality of Work Life of Employees in Salzer Electronic Private Limited, Coimbatore, Journal of Management (JOM) Volume 5, Issue 6, November-December 2018, pp. 116-115.

[12] www.wikipedia.com/about quality of work life

[13] www.humanresource.com

[14] www.citehr.com 